\title{
Analysis of the Use of Virtual Meeting in the Implementation of Proposal/Thesis Examination During Covid-19 Pandemic
}

\author{
Dodik Arwin Dermawan ${ }^{1, *}$ Rindu Puspita Wibawa ${ }^{1}$ Martini D E Susanti ${ }^{1}$
}

\author{
${ }^{1}$ Department of Informatics Engineering, Universitas Negeri Surabaya, Surabaya, Indonesia \\ *Corresponding author. Email: dodikdermawan@unesa.ac.id
}

\begin{abstract}
In the early 2020s, Indonesia was shocked by the Coronavirus Disease (Covid-19) outbreak which struck almost all parts of the world. The Indonesian government spontaneously implemented a policy of learning from home, working from home, and worship at home. All face-to-face activities are diverted online. In the field of education, both universities and schools need to strengthen online learning during this time. Universitas Negeri Surabaya has an alternative in carrying out a proposal / thesis seminar by using virtual meetings. The virtual meetings used include: meeting.unesa.ac.id, rv.unesa.ac.id, zoom, google meets, Webex and others. This study aims to determine students' perceptions of the virtual meeting features as a means of online proposal / thesis examination in the middle of a pandemic. This study can be a reference whether the use of virtual meetings as an alternative in carrying out a seminar proposal / thesis is effectively implemented. The research focuses on students' opinions on the usability factor (PU) and convenience factor (PEOU) in virtual meeting features following the Technology Acceptance Model theory. This research was conducted by quantitative methods. The sample used in this study were students of Universitas Negeri Surabaya who were taking the thesis. Data collection techniques using a questionnaire with a Likert scale. Then the results of the questionnaire data are processed using the Structural Equation Model (SEM) with SPSS tools. The results of the study stated that the research indicators related to user satisfaction in utilizing virtual meetings as an alternative for implementing seminar proposals / theses passed the validity, reliability, and linearity tests. Validity test value> $r$ table. The value of the alpha reliability test was between $0.70-0.90$. While the linearity test value>0.05.
\end{abstract}

Keywords-Technology Acceptance Model, virtual meeting, Covid-19

\section{INTRODUCTION}

Indonesia in early 2020 is being shocked by the outbreak of the Coronavirus Disease (Covid-19) which has hit almost all parts of the world (Mahase, 2020). Covid-19 started in Wuhan, China (1), and has been declared a pandemic by the World Health Organization (WHO) (2). Various countries have implemented social distancing (social distancing) which is designed to reduce interactions between people in a wider community, where individuals may be infected but have not been identified and thus have not been isolated (3). Indonesia spontaneously implemented policies of learning from home, working from home, and worshiping at home. Higher education during the WFH period needs to strengthen online learning (4).
Various platforms can be used to support online learning (Bensalem, 2018). Both are managed independently by the institution using a Learning Management System (LMS) or those provided freely by third parties. The online learning services is forming by ubiquitous learning, social networks (communities), mobile technologies, and personalized knowledge management [5]. Learning process at Universitas Negeri Surabaya carried out online using e-learning, vilearning, mailing lists, chat groups, video conferences, etc. Online learning is considered as alternative learning independently for assisting or improving the traditional classroom teaching [6]. With the online learning, the lecturer expected to be creative in making media, materials, and evaluation methods used so that the learning process could run effectively [7]. Universitas Negeri Surabaya in carrying out the 
proposal/thesis seminar has an alternative, namely using virtual meetings. The virtual meetings used include: meeting.unesa.ac.id, rv.unesa.ac.id, zoom, google meets, Cisco Webex and others. This is something new and is soon being adapted by both lecturers and students. For this reason, it is important to know how student acceptance is an alternative to implementing a seminar proposal/thesis using virtual meetings.

Students are one of the parties who feel the use of the virtual meeting feature as a means of implementing online examination proposals/theses. Problems that arise from the aspect of human behavior, such as the difficulty of changing behavior can be a barrier to developing the use of information technology. In general, research on the acceptance of information technology is based on the Technology Acceptance Models (TAM) introduced by [8], explaining that an individual acceptance of technology computers that are based on two beliefs, namely: a). Perceived Usefulness (PU), namely the level at which a person thinks that using a system will improve his performance; b). Perceived Ease of Use (PEOU), which is the level of someone believing that using technology requires very little effort. TAM is considered to be able to make the best contribution in predicting and explaining user acceptance of computer technology in organizations [9]. In the TAM theory, these two beliefs determine the behavior of acceptance of information technology directly.

Based on the results of this study, researchers are very interested in research by looking at the behavior of student admissions to the virtual meeting feature in supporting the implementation of the proposal/thesis seminar during the Covid-19 pandemic based on two beliefs, namely Perceived Usefulness (PU) and Perceived Ease of Use (PEOU).

\subsection{Virtual Meeting}

In everyday life, we are often faced with the word "meeting" in all sectors of life, whether in business, politics, or education. With the development of technology, the need for meetings can now be more easily fulfilled without being limited by space and time, namely by using virtual meetings. According to [10], a virtual meeting is an activity in which all participants from various locations join in a pre-agreed time using a medium such as a teleconference or a video conference.

The use of virtual meetings according to several studies that have been conducted by experts, can save costs significantly in terms of time and costs. Especially in the era of the Covid-19 pandemic which requires everyone to study and work from home, this virtual meeting technology is considered very effective for everyone to be able to be productive in activities even though they are at home. The selection of the right technology must be done to get maximum results as well.

\subsection{Technology Acceptance Model (TAM)}

Davis et al. [8] has developed a model that explains individual behavior in the acceptance of information technology called TAM. This TAM was developed from a psychological theory that explains that user behavior starts from belief, attitude, intention, and user behavior relationship. This model is contained in the attitudes of each user behavior and has two variables, namely ease of use (ease of use) and usefulness (usefulness). The TAM model can explain that user perceptions will determine their attitudes in the use of information technology and describe more clearly the use of information technology which is influenced by usefulness and ease of use. There are 4 constructs used in TAM research, namely: Perceived Ease Of Use, Perceived Usefulness, Attitude Toward Using, and Actual Usage. Perceived Ease of Use Perceived ease of use in technology is defined as a measure of one's trust in computers that are easy to understand and use [8]. This explanation is supported by [11] which explains that perceived ease of use of technologyis defined as a measure in which someone believes that the technology is easy to understand and easy to use.

\subsection{Structural Equation Models (SEM)}

Structural Equation Models is one of the famous and useful statistic methods that describe relationships between variables. SEM are similar to combining multiple regression and factor analysis. They are also offer some important and additional benefits over these techniques including an effective way to deal with multicollinearity, and methods for taking into account the unreliability of consumer response data. SEM can be used with many statistical tools such as SPSS, AMOS, minitab, etc [12].

\section{METHOD}

This research method is quantitative research with a participatory approach. This research applies a literature study, as well as field studies. The data was collected by distributing questionnaires to the final students of the State University of Surabaya. The questionnaire was prepared based on the PU and PEOU attributes of the TAM. The research focus is on student admission to the virtual meeting feature as a means of implementing a proposal/thesis exam.

The data collected will be processed using the Structural Equation Model (SEM) method with SPSS tools. Student admission data will be analyzed and classified according to performance improvement (PU) 
and ease of use (PEOU) regarding the virtual meeting feature as a means of implementing a seminar proposal/thesis.

\section{RESULT AND DISCUSSION}

\subsection{Descriptive Statistical Analysis}

Descriptive statistical analysis was conducted to describe the respondent's perception of the variable statement questions on the research instrument. This analysis is carried out by calculating the average (mean) of the percentage of respondents' responses on each item in all indicators in one variable. From this mean value, a further description is carried out to interpret the research variables, namely Perceived ease of use, Perceived usefulness, and Behavioral intention. If the resulting mean value is close to number four, it shows that the respondent's perception is very good in responding to the statement submitted. Meanwhile, the mean value which is close to 1 indicates that the respondent's perception is very bad. The following is a descriptive statistical analysis of each variable.

Table1. Mean Test

\begin{tabular}{|c|c|c|}
\hline \multicolumn{2}{|c|}{ Variable } & Mean \\
\hline X11 & Perceived ease of use & 2.98 \\
\hline X12 & Perceived usefulness & 3.02 \\
\hline Y & Behavioral intention & 3.25 \\
\hline
\end{tabular}

The mean test table states that the three variables have a test value close to 3 and greater than 3 . This means that students can accept the use of virtual meetings as an alternative tomholding a seminar proposal/thesis. Students find it easy and have benefits in using virtual meetings as a substitute for online seminars. So, they tend to reuse virtual meetings at a later date.

\subsection{Validity Test}

The validity test is a measure to measure the validity of the questionnaire results. Pearson correlation test can be done because it can eliminate the nature of subjectivity in one respondent regarding the answer to each question. In this test, the item score will be correlated with the total item score, then the significance test is carried out with the criteria using the $r$ table at the 0.05 significance level with a 2 -sided test. If the positive value $r$ count $\geq r$ table, then the item can be declared valid, and vice versa if $r$ count $\leq r$ table then the item is invalid. The following are the results of the validity test for each variable.

The r-table value used was obtained from the $\mathrm{df}=$ $\mathrm{N}-2$ value with a significance level of 0.05 where $\mathrm{N}=$ 37 . Then the r-table value is 0.320 . In the tables, it can
Table 2. Validity of Preceived Ease of Use Variable

\begin{tabular}{|c|c|c|c|}
\hline $\begin{array}{c}\text { Variable } \\
\text { Indicator }\end{array}$ & Value & r table & Explanation \\
\hline $\mathrm{X} 11$ & 0.802 & 0,320 & Valid \\
\hline $\mathrm{X} 12$ & 0.671 & 0,320 & Valid \\
\hline $\mathrm{X} 13$ & 0.773 & 0,320 & Valid \\
\hline $\mathrm{X} 14$ & 0.612 & 0,320 & Valid \\
\hline $\mathrm{X} 15$ & 0.845 & 0,320 & Valid \\
\hline
\end{tabular}

be seen the value of the Pearson correlation (correlation validity) which can be compared with the r-table. And the result is that all question items in each indicator of human behavior have a value of $\geq 0.320$ so that it can be said to be valid. So that it can be used for further analysis.

Table 3. Validity Test of Perceived of Usefulness Variable

\begin{tabular}{|c|c|c|c|}
\hline $\begin{array}{c}\text { Variable } \\
\text { Indicator }\end{array}$ & Value & r table & Explanation \\
\hline $\mathrm{X} 21$ & 0.878 & 0,320 & Valid \\
\hline $\mathrm{X} 22$ & 0.923 & 0,320 & Valid \\
\hline $\mathrm{X} 23$ & 0.899 & 0,320 & Valid \\
\hline $\mathrm{X} 24$ & 0.887 & 0,320 & Valid \\
\hline $\mathrm{X} 25$ & 0.757 & 0,320 & Valid \\
\hline
\end{tabular}

The r-table value used was obtained from the $\mathrm{df}=$ $\mathrm{N}-2$ value with a significance level of 0.05 where $\mathrm{N}=$ 37 . Then the r-table value is 0.320 . In the tables, it can be seen the value of the Pearson correlation (correlation validity) which can be compared with the r-table. And the result is that all question items in each indicator of human behavior have a value of $\geq 0.320$ so that it can be said to be valid. So that it can be used for further analysis.

Table 4. Validity Test of Behavioral Intention Variable

\begin{tabular}{|c|c|c|c|}
\hline $\begin{array}{c}\text { Variable } \\
\text { Indicator }\end{array}$ & Value & r table & Explanation \\
\hline Y1 & 0.926 & 0,320 & Valid \\
\hline Y2 & 0.925 & 0,320 & Valid \\
\hline
\end{tabular}

The r-table value used was obtained from the $\mathrm{df}=$ $\mathrm{N}-2$ value with a significance level of 0.05 where $\mathrm{N}=$ 37 . Then the r-table value is 0.320 . In the tables, it can be seen the value of the Pearson correlation (correlation validity) which can be compared with the r-table. And the result is that all question items in each indicator of human behavior have a value of $\geq 0.320$ so that it can be said to be valid. So that it can be used for further analysis. 


\subsection{Reliability Test}

Reliability is a measure of the consistency and stability of the questionnaire if measurements are repeated. In the reliability test as the value of $r$, the result is the value of "Cronbach's Alpha". To determine whether a construct is reliable or not, you can use the Alpha value limit as follows:

1. If alpha $>0.90$, reliability is perfect

2. If the alpha is between $0.70-0.90$, the reliability is high

3. If alpha is between $0.50-0.70$, the reliability is moderate

4. If alpha $<0.50$ then reliability is lowBerikut adalah hasil uji reliabilitas untuk seluruh variable.

Table 5. Reliability Test

\begin{tabular}{|c|c|c|}
\hline Variable & $\begin{array}{c}\text { Cronbach's } \\
\text { Alpha (N=37) }\end{array}$ & Explanation \\
\hline $\begin{array}{c}\text { Perceived ease of } \\
\text { use }\end{array}$ & 0,789 & $\begin{array}{c}\text { High } \\
\text { Reliability }\end{array}$ \\
\hline $\begin{array}{c}\text { Percieved } \\
\text { usefulness }\end{array}$ & 0,919 & $\begin{array}{c}\text { Perfect } \\
\text { Reliability }\end{array}$ \\
\hline $\begin{array}{c}\text { Behavioral } \\
\text { intention }\end{array}$ & 0,833 & $\begin{array}{c}\text { High } \\
\text { Reliability }\end{array}$ \\
\hline
\end{tabular}

The table above shows that the reliability value (Cronbach's alpha) on all variables is above 0.5 , so it can be stated that the data is reliable.

\subsection{Linearity Test}

The linearity test aims to determine whether two variables have a significant linear relationship or not. Good data should have a linear relationship between the predictor variable $(\mathrm{X})$ and the criterion variable $(\mathrm{Y})$. In several references, it is stated that this test is used as a prerequisite in correlation analysis or linear regression. The basis for decision making in the linearity test can be done by looking at the significance value at the SPSS output, that is, if the significance value is greater than 0.05 , the conclusion is that there is a significant linear relationship between variables $X$ and Y. Conversely, if the significance value is less than 0.05 . then the conclusion is that there is no linear relationship between variables $\mathrm{X}$ and $\mathrm{Y}$. The results of the linearity test for these 3 variables are:

1. Perceived ease of use on Behavioural intention the output of the linearity test obtained a significance value $=1.804$. This value is greater than 0.05 , which means that there is a significant linear relationship between the Perceived ease of use variable and Behavioral intention. So that it can be used for further analysis.

2. Perceived usefulness for Behavioral intention. The output of the linearity test obtained a significance value $=0.795$. This value is greater than 0.05 , which means that there is a significant linear relationship between the Perceived usefulness variable and Behavioral intention. So that it can be used for further analysis.

\section{CONCLUSION}

In research using a questionnaire, the initial stage that must be done is testing the validity and reliability of the questionnaire. This test is intended to ensure the accuracy and objectivity of the measured data. The validity test states that the three variables with each item are valid for use in this study. This is stated by the validity correlation value greater than the r-table value (> 0.320). The reliability test states that the three variables meet the existing reliable criteria, namely the reliability value is greater than 0.05 . Furthermore, the linearity test was carried out on the three variables. The results were obtained to state that the three variables have a linear relationship. Expressed with a significant value greater than 0.05 .

From the results of the mean test, it is stated that the average answer from students has a value above 3 . So it can be concluded that students in using virtual meetings as an alternative seminar proposal/thesis find it easy and useful. So that in the future students have the desire to use virtual meetings as a means of seminar proposals/theses on an ongoing basis. The desire to use sustainably will turn into a habit. If you are used to it, it can be concluded that the adaptation was successful.

This research is only limited to the analysis of student admissions to virtual meetings as an alternative to the seminar proposal/thesis using the TAM that has been identified in the model. Subsequent research can focus on extracting these variables through interviews with users in the context of student admission to virtual meetings as an alternative to seminar proposals/theses.

\section{REFERENCES}

[1] Shi, H. H., Jiang, N., Cao, Y., Alwalid, O., Gu, J., Fan, Y., \& Zheng, C. (2020). Radiological findings from 81 patients with COVID-19 pneumonia in Wuhan, China: a descriptive study. The Lancet Infectious Diseases.

[2] Sohrabi, C., Alsafi, Z., O'Neil, N., Khan, M., Kerwan, A., Al-Jabir, A., . . Aghad, R. (2020). World Health Organization declares global emergency: A review of the 2019 novel coronavirus (COVID-19). International Journal of Surgery

[3] Smith, A. W., \& Freedman, D. O. (2020). Isolation, quarantine, social distancing, and community containment: a pivotal role for oldstyle public health measures in the novel 
coronavirus (2019-nCoV) outbreak. Journal of Travel Medicine.

[4] Darmalaksana, W. (2020). WhatsApp Kuliah Mobile .Fakultas Ushuluddin UIN Sunan Gunung Djati Bandung.

[5] A. Lau and E. Tsui, "Knowledge management perspective on e-learning effectiveness," Knowledge-Based Syst., vol. 22, no. 4, pp. 324325, 2009.

[6] R. J. Chao and Y. H. Chen, "Evaluation of the criteria and effectiveness of distance e-learning with consistent fuzzy preference relations," Expert Syst. Appl., vol. 36, no. 7, pp. 1065710662, 2009.

[7] H. EL-Deghaidy and A. Nouby, "Effectiveness of a blended e-learning cooperative approach in an Egyptian teacher education programme," Comput. Educ., vol. 51, no. 3, pp. 988-1006, 2008.
[8] Davis, Fred. D, (1989), "Perceived Usefulness, Perceived Ease of Use, and Use Acceptance of Information Technology", MIS Quarterly, pp. 318-340.

[9] Schillewaert, Niels, Michael Ahearne, Rund Frambach, and Rudy K. Moenaert, (2000), "The Acceptance of Information Technology In The SalesForce" Journal of Marketing, December 11, Institute for The Study of Business Markets (ISBM), Pennsylvania. http://www.ebusiness.xerox.com/

[10] https://www.facilitate.com/article/11288-gettinggreat-results-from-virtual-meetings

[11] Arief Wibowo, 2006, Kajian tentang Perilaku Pengguna Sistem Informasi dengan Pendekatan Technology Acceptance Model (TAM), Universitas Budi Luhur, Jakarta.

[12] Bacon,Lynd. (1997). Using Amos for Structural Equation Modeling in Market Research. 